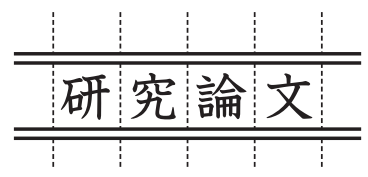

\title{
最適化問題の自動階層分割手法と 3DLSI 概略設計への適用 \\ Automated Dividing Method for Hierarchical Optimizationand Application to 3DLSI Rough Design
}

\author{
寺田識史*・岩田剛 治**・村田秀則***・河村＼cjkstart憲**** \\ Satoshi TERADA, Yoshiharu IWATA, Hidenori MURATA and Ken KAWAMURA
}

(Received February 21. 2018)

\begin{abstract}
This research focused on a decomposition type optimization method that makes it easier to solve individual optimization problems by dividing the optimization problem into smaller optimization problems in multiple design spaces. Then, based on the parametric relationship of the product system model, a hierarchical optimization method to divide the optimization problem into optimizable optimization problems that can definitely define the objective function was studied. For this purpose, this research focused on the dependency relationship between the design variables of the optimization problem and the objective function and constructed an algorithm that divides and hierarchizes the optimization problem into an optimizable problem, which can be definitely defined by the objective function. By using this algorithm, this research adapted this method for 3DLSI rough design. As a result, we get the proper definition of optimization problem.
\end{abstract}

Key Words: Optimization, Production-System Model, Decomposition Optimization, Hierarchical Optimization

\section{1. 緒 言}

最適化アルゴリズムはこれまで多くの研究がなされてき たが 1)-6)、基本的にどのアルゴリズムも、大規模問題に対 応できているとは言い難い。原因の 1 つは、大規模問題は 設計空間が大規模であるために、目的関数值の傾向を把握 し切れないためである。

この問題に対するアプローチとして、最適化問題を複数 の設計空間の比較的小さい最適化問題に分割することに よって、個々の最適化問題を解きやすくする分割型の最適 化手法が注目されている。

分割型の最適化手法の中で最も多くの研究がなされてい るのが、階層型最適化手法である ${ }^{77-10)}$ 。階層型最適化手法は、 分割した最適化問題を階層的に分割して解いて、その結果 を統合することにより元の最適化問題の最適解を導出する 手法である。

この手法の課題は、最適化問題の分割・階層化の操作が 使用者の手作業である点と、分割された最適化問題が、目
的関数を定義できるかの可否判断である。

現状では階層型最適化手法の分割・階層化アルゴリズム の多くは、モノや機能の観点での分割を採用している。し かし、モノや機能の観点での分割は、最適化問題としての 視点が考慮されていないため、分割された最適化問題がど うなるかまでは考慮できていない。結果的に、最適化でき ない問題を生み出すことになり、計算を複雑にして、最適 解が得られないという事態に陥ってしまう。

そこで本研究では、最適化問題を、確実に目的関数が定 義できる、最適化可能な最適化問題に分割する階層型最適 化手法について検討を行い、その手法を 3DLSI の概略設計 に適用した結果を報告する。

\section{2. 新階層型最適化問題分割手法の構築}

\section{1 分割・階層化アルゴリズムの概要}

最適化問題に最低限必要となるものは設計変数と目的関 数である。最適化問題を分割する際には各最適化問題に設 計変数と目的関数を定義する必要がある。この分割を行う

*大阪大学 大学院工学研究科 マテリアル生産科学専攻（現パナソニック株式会社）

（テ565-0871 吹田市山田丘2-1）（テ135-0063 東京都江東区有明3-4-10 TFT ビル西館5 階）

Division of Materials and Manufacturing Science, Graduate School of Engineering,Osaka University (currently Panasonic Corporation)

(2-1 Yamada-oka, Suita, Osaka 565-0871, Japan) (TFT Building West-wing 5F, 3-4-10, Ariake, Koto-ku, Tokyo 135-0063, Japan)

* *大阪大学大学院工学研究科 マテリアル生産科学専攻（テ565-0871 吹田市山田丘2-1）

Division of Materials and Manufacturing Science, Graduate School of Engineering,Osaka University (2-1 Yamada-oka, Suita, Osaka 565-0871, Japan)

***大阪大学 大学院工学研究科 マテリアル生産科学専攻（現機械工学専攻）( 个 565-0871 吹田市山田丘 2-1)

Division of Materials and Manufacturing Science, Graduate School of Engineering,Osaka University (currently Division of Mechanical Engineering) (2-1 Yamada-oka, Suita, Osaka 565-0871, Japan)

****大阪大学大学院工学研究科 マテリアル生産科学専攻（現ダッソー・システムズ株式会社）

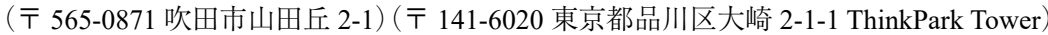

Division of Materials and Manufacturing Science, Graduate School of Engineering,Osaka University (currently Dassault Systèmes K.K.)

(2-1 Yamada-oka, Suita, Osaka 565-0871, Japan) (ThinkPark Tower, 2-1-1 Osaki, Shinagawa-ku, Tokyo 141-6020, Japan) 


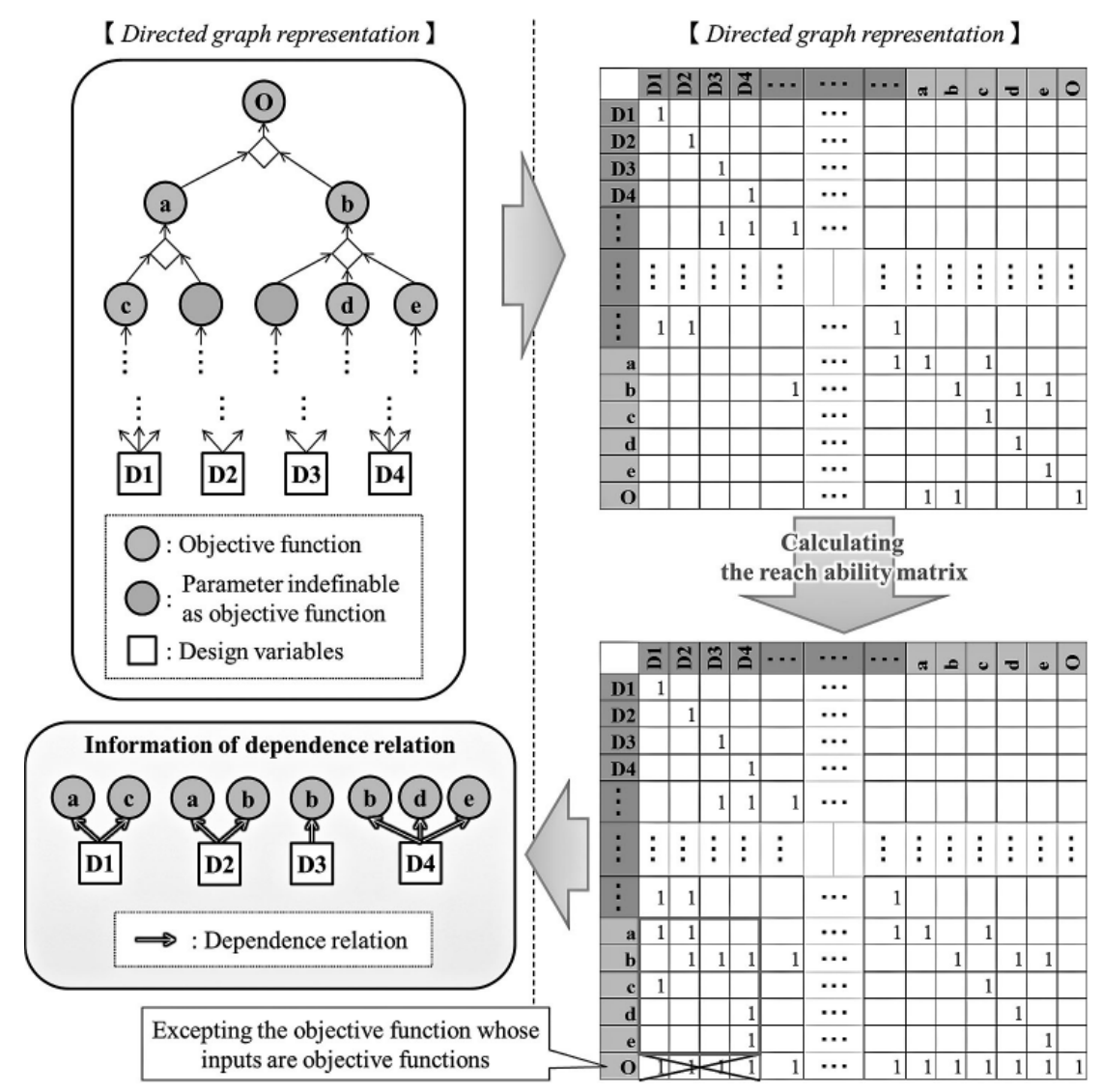

Fig. 1 Flow of analysis of dependence relation between design variables and objective function using the reach ability matrix.

際の留意点として、共通の目的関数に依存する設計変数は 独立に最適化できないことが挙げられる。このことから、 設計変数に対してそれぞれ異なる目的関数を割り振り、そ れらの依存関係を見極めることによって、相互作用を生じ ない範囲で可能な限り最適化問題を分割するという分割・ 階層化アルゴリズムを提案する。

\section{2 最適化方向の割り当て}

最適化問題の目的関数は、定義された数だけしか存在し ない。しかし、実際の最適化問題は目的関数と設計変数た けではなく、その間に複数のパラメータを介している設計 変数でも目的関数でもないこのパラメータ（以下、中間パラ メータとする)の中から目的関数になり得るパラメータを探 すことが分割・階層化アルゴリズムの最初の操作である。

具体的には中間パラメータに割り当てる最適化方向を決 めるために、関係式の分析を行う。目的関数から関係式を 逆に逆っていき、中間パラメータの最適化方向が何なのか を分析していくことで、目的関数になり得る中間パラメー 夕を明確化していく。

\section{3 設計変数と目的関数の依存関係の明確化}

関係式の分析の操作では、中間パラメータの最適化方向 を分析し、最適化方向の明確なものを目的関数として定義し
た。その次に行うのは、設計変数がどの目的関数に依存する かを明確化する操作である。この操作の目的は、共通の目的 関数に依存する設計変数は分けて独立に最適化できないこ とから、各設計変数の依存する目的関数を明確化して、分け て最適化できるかどうかの判断材料を得るためである。さら に、これらの操作により制約条件は影響を受けないので、制 約を受ける変数に応じた最適化問題に割り当てればよい。

\section{4 設計変数 - 目的関数の依存関係分析}

関係式の分析によって中間パラメータに最適化方向を割 り当てて、目的関数を新たに定義した後、次に行うのは、 設計変数とその目的関数の依存関係を調べることである。

そこで、最適化問題のパラメータの関係を有向グラフと して捉え、可到達行列を求めることにより設計変数がどの 目的関数に依存するかが分かる。

この可到達行列を用いた、設計变数と目的関数の依存関 係分析の流れを Fig. 1 に示す。まず、求めた可到達行列の 設計变数の要素がある列と目的関数の要素がある行の交点 に、依存関係を表す「1」があれば、その設計変数から目的 関数に対して依存関係があると判断できる。ただしこの時、 設計変数に対して全ての目的関数との依存関係を見ること はしない。目的関数の内、その入力のパラメータも全て目 的関数になっているものとの依存関係はあえて無視する。 


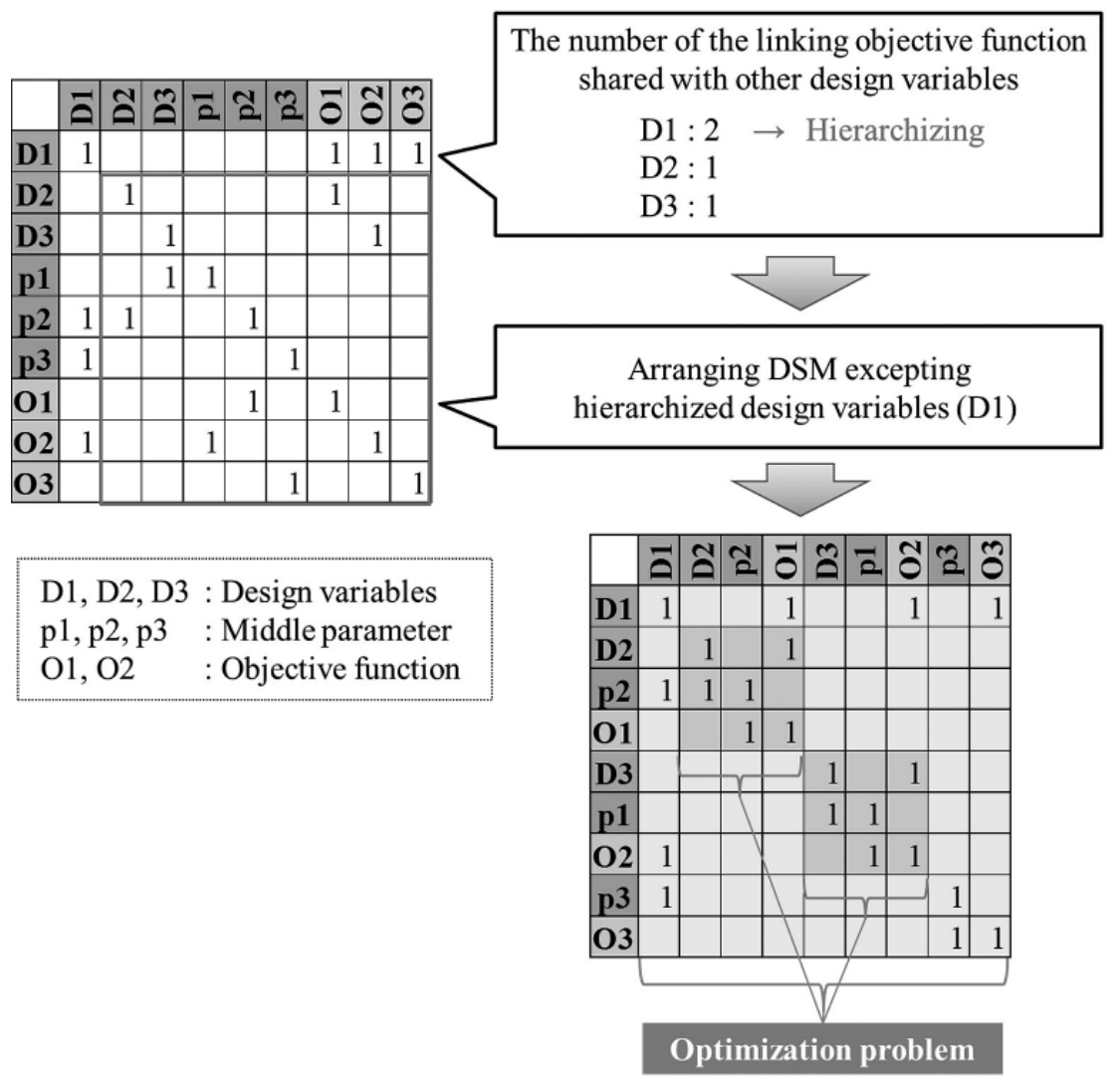

Fig. 2 Hierarchization of optimization problem using DSM.

その理由は、その目的関数に辿り着くまでに既に他の目的 関数に必ず辿り着いていることと、その目的関数への対応 関係を入れてしまうと設計变数間に共通する目的関数が増 えてしまい、分割の弊害になる可能性があることである。

以上のアルゴリズムを基に、各目的関数において行列の 計算によって設計変数と目的関数間の依存関係の情報を自 動的に抽出するプログラムを構築した。

これらの情報を元に最適化問題の分割可能場所が選定さ れるので、それらの場所すべてで階層化を行い階層型最適 化問題の定義が可能となる。

\section{5 自動分割・階層化アルゴリズム}

この分割を行う操作では、村田らの研究で用いられてい る方法を参考にした ${ }^{11)}$ 。村田らの研究では、最適化問題を システムモデリングッールの Design Structure Matrix (DSM) ${ }^{12)}$ を用いて、行列で表現・整理している。このDSMの行列 は、先に出てきたパラメータの依存関係を行列で表したも のと同様である。ここで、村田らの研究では、最適化特有 の目的関数の值の評価から設計变数の值の变更を行うとい う操作を、目的関数から設計变数への依存関係として DSM に定義している。これを定義することによって、DSM を整 理すると、設計変数から目的関数を導出し、その目的関数 值を評価し、設計変数值を変更するという最適化の計算つ ローが明確になる。さらに、異なる目的関数に依存する設
計変数は異なる最適化フローに分けられるため、DSM の整 理によって分割の操作も可能になる。よって分割の操作は、 DSM の整理プログラムによって実現することにした。

分割をDSM 上で操作するため、階層化も DSM を用いて 実現することにした。DSM を用いた階層化の流れを Fig. 2 に示す。DSM 上では、設計変数と目的関数の依存関係は、 目的関数から設計変数への依存関係として表されている。 この情報から、各設計変数の、他の設計変数と共通してい る目的関数の数を数える。その数が一番大きい設計変数を 階層化し、その設計変数を除く、DSM の残りの部分を整理 することで、最適化問題を分割するといった流れになる。

以上のように、DSMを用いた分割と階層化のアルゴリズ ムをプログラム化し、自動分割・階層化を実行する形とし た。このアルゴリズムの概要を Fig. 3 に示す。

\section{3. 新階層型最適化問題分割手法の 3DLSI 概略設計への適用}

\subsection{DLSI 概略設計モデル}

本研究では、このような背景から 3 次元 LSI の設計の最 適化問題を検証モデルに採用した。3 次元 LSI のモデル図 を Fig. 4 に示す。また、Fig. 5 にこの今回の 3 次元 LSI モ デルの階層構造図を示す。

3.2 最適化問題の自動分割・階層化の実行結果

3 次元 LSI の設計の最適化問題に対して、本研究で構築 
した自動分割・階層化手法を実行した結果を示す。この実 行結果を基に、構築した分割・階層化アルゴリズムと自動 分割・階層化アルゴリズムの検証・考察を行う。また、比

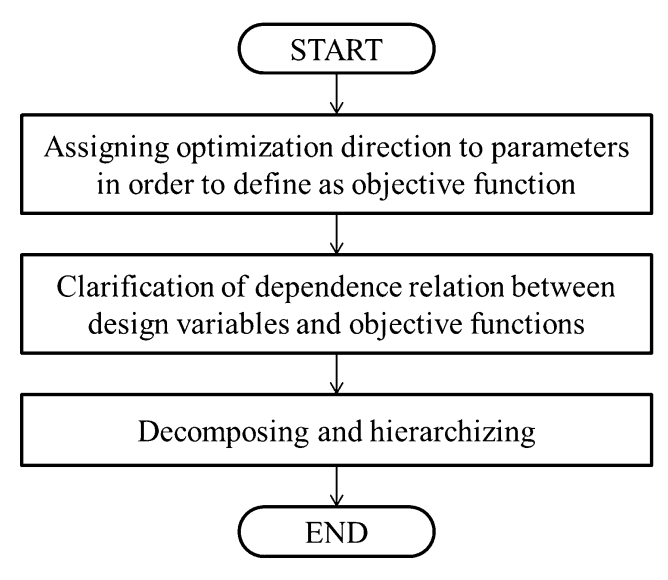

Fig. 3 Flowchart of decomposing/hierarchizing algorithm.
較対象として、従来の階層型最適化手法のモノと機能の観 点での分割・階層化アルゴリズムによる分割・階層化の結 果も示す。

（a）従来の階層型最適化手法の分割・階層化の実行結果

まず、本研究で構築した分割・階層化アルゴリズムの比 較対象として、従来提案されてきた階層型最適化手法の分 割・階層化アルゴリズムによる分割・階層化の結果を示す。

従来の階層型最適化手法の分割・階層化アルゴリズムは、 モノの観点での分割と機能の観点での分割であった。まず、 3 次元 LSI の設計の最適化問題をモノの観点で分割・階層化 した結果を Fig. 6 に示す。Fig. 6 では分割された最適化問題 の全ての詳細は割愛するが、例としてロジックチップの最適 化問題の詳細を記述した。Fig. 6 から分かるように、ロジッ クチップの最適化問題から LSI の最適化問題に伝達されるパ ラメータの内、ロジックチップ駆動周波数が最適化方向が分 からず、目的関数として定義できない。このように、目的関 数が定義できず、最適化できない問題が他にも多々あり、最

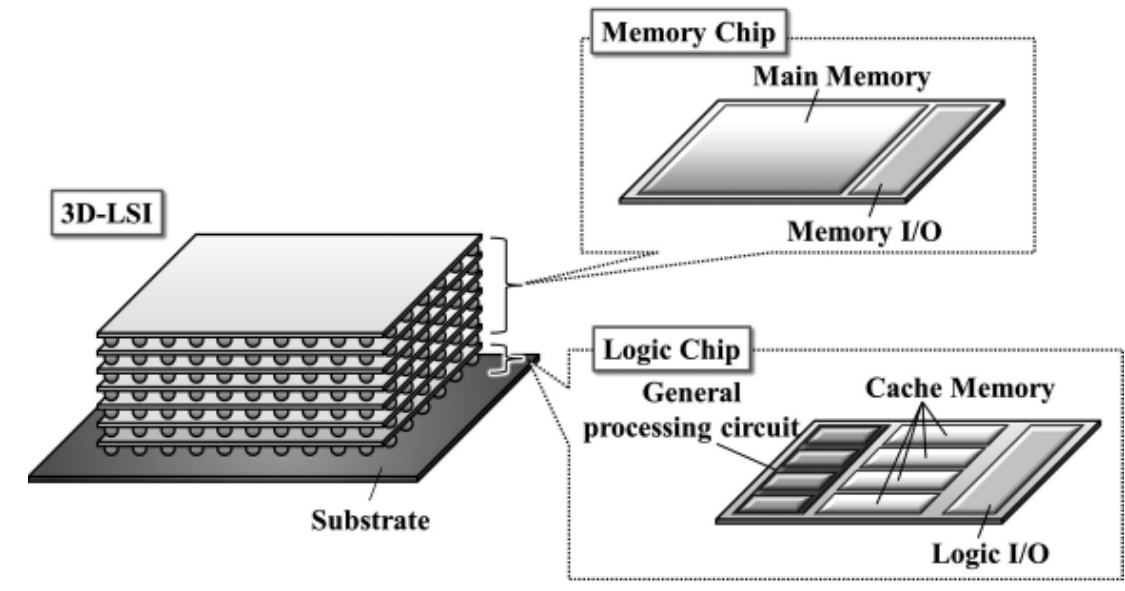

Fig. 4 3D-LSI structure.

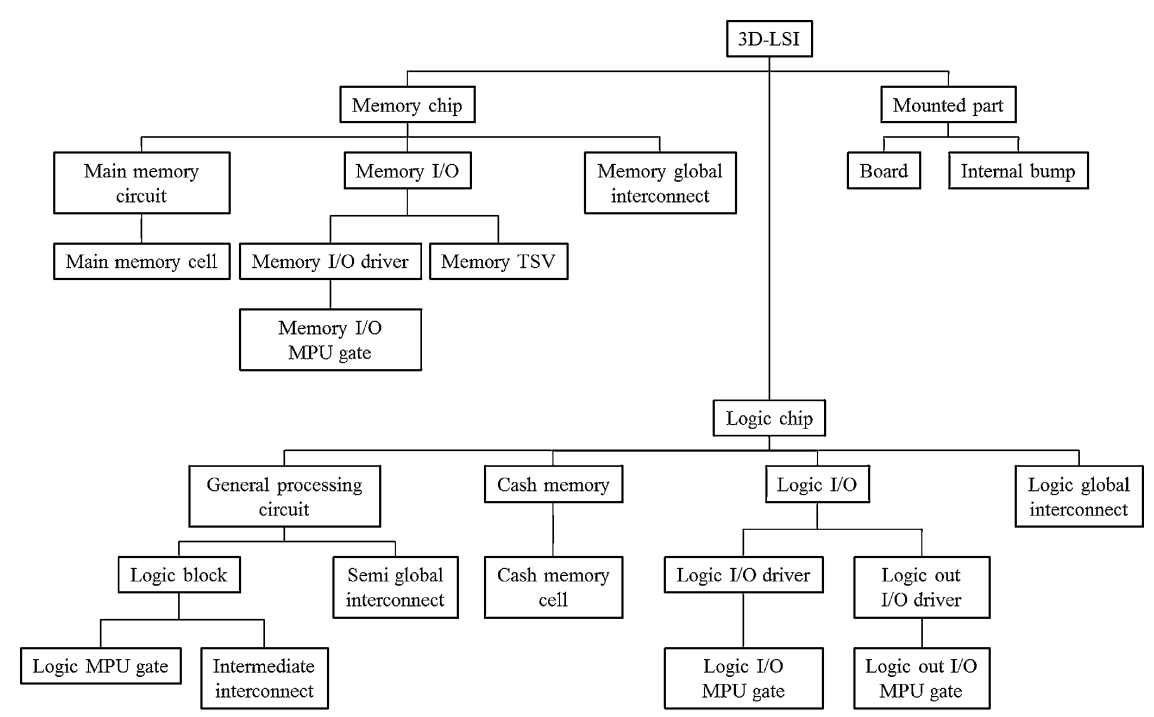

Fig. 5 Hierarchical component structure of 3D-LSI. 


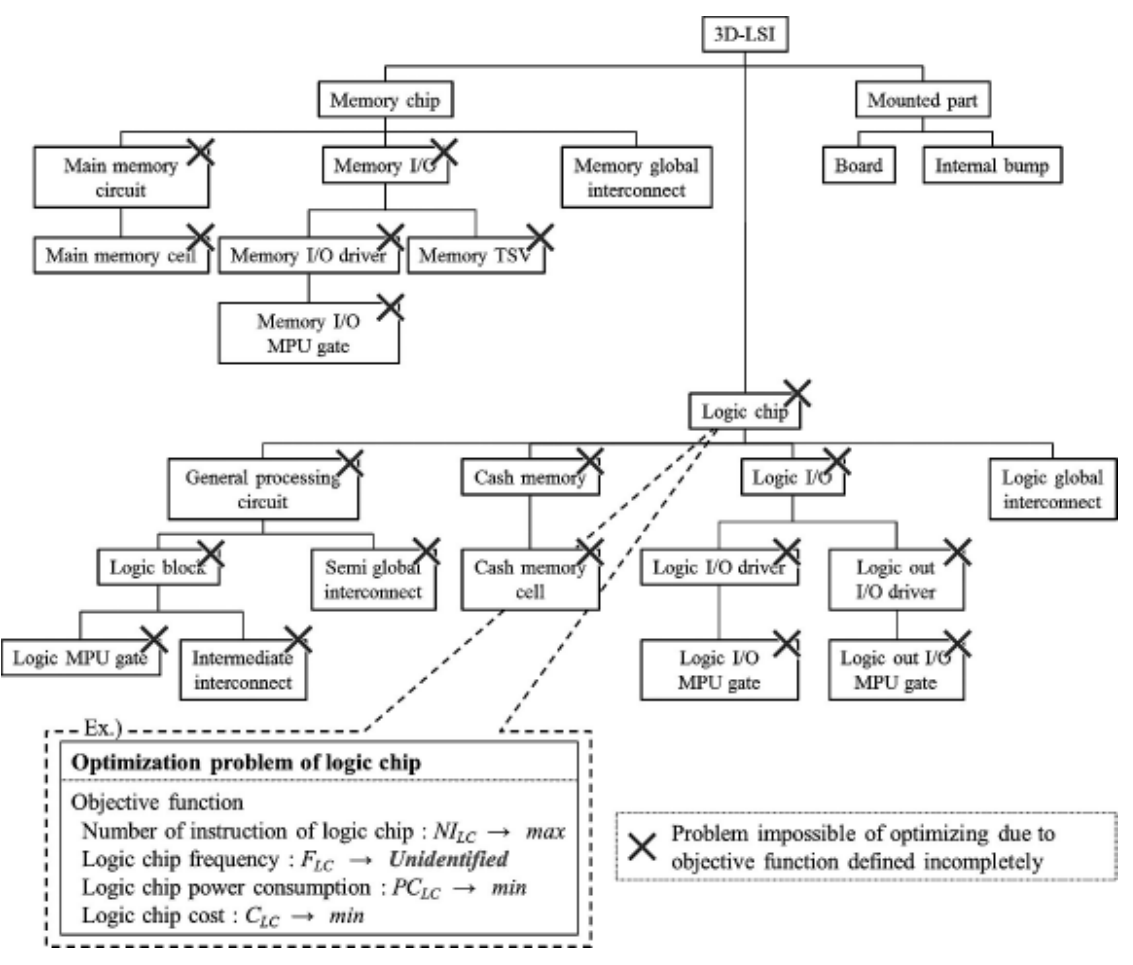

Fig. 6 Object-based hierarchical decomposition of 3D-LSI optimization problem.

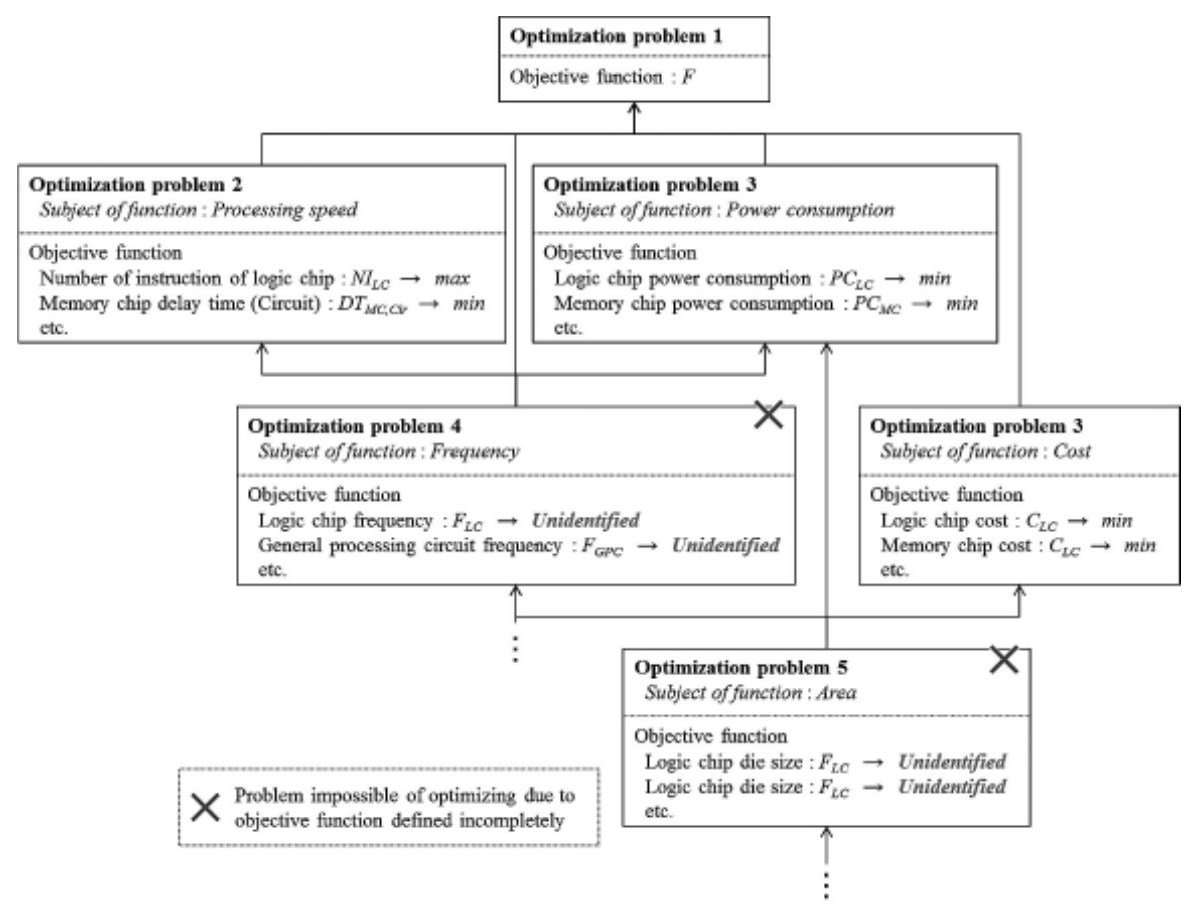

Fig. 7 Function-based hierarchical decomposition of 3D-LSI optimization problem.

適化が非常に困難になっていることが分かる。

次に、3 次元 LSI の設計の最適化問題を機能の観点で分 割・階層化した結果を Fig. 7 に示す。Fig. 7 の例では、3 次元 LSI の機能を処理速度、消費電力、コスト、周波数、 面積に分けて階層化している。目的関数が定義できずに、 最適化できない問題は、モノの観点での分割よりは少ない
ものの、いくつか存在し、最適化が難しくなっていること が分かる。

以上のように、従来の階層型最適化手法では、3 次元 LSI の設計の最適化問題でも、目的関数が定義できず、最適化 できない問題に分けてしまうという事態が起こり、最適化 を難しくしてしまうことを確認した。 


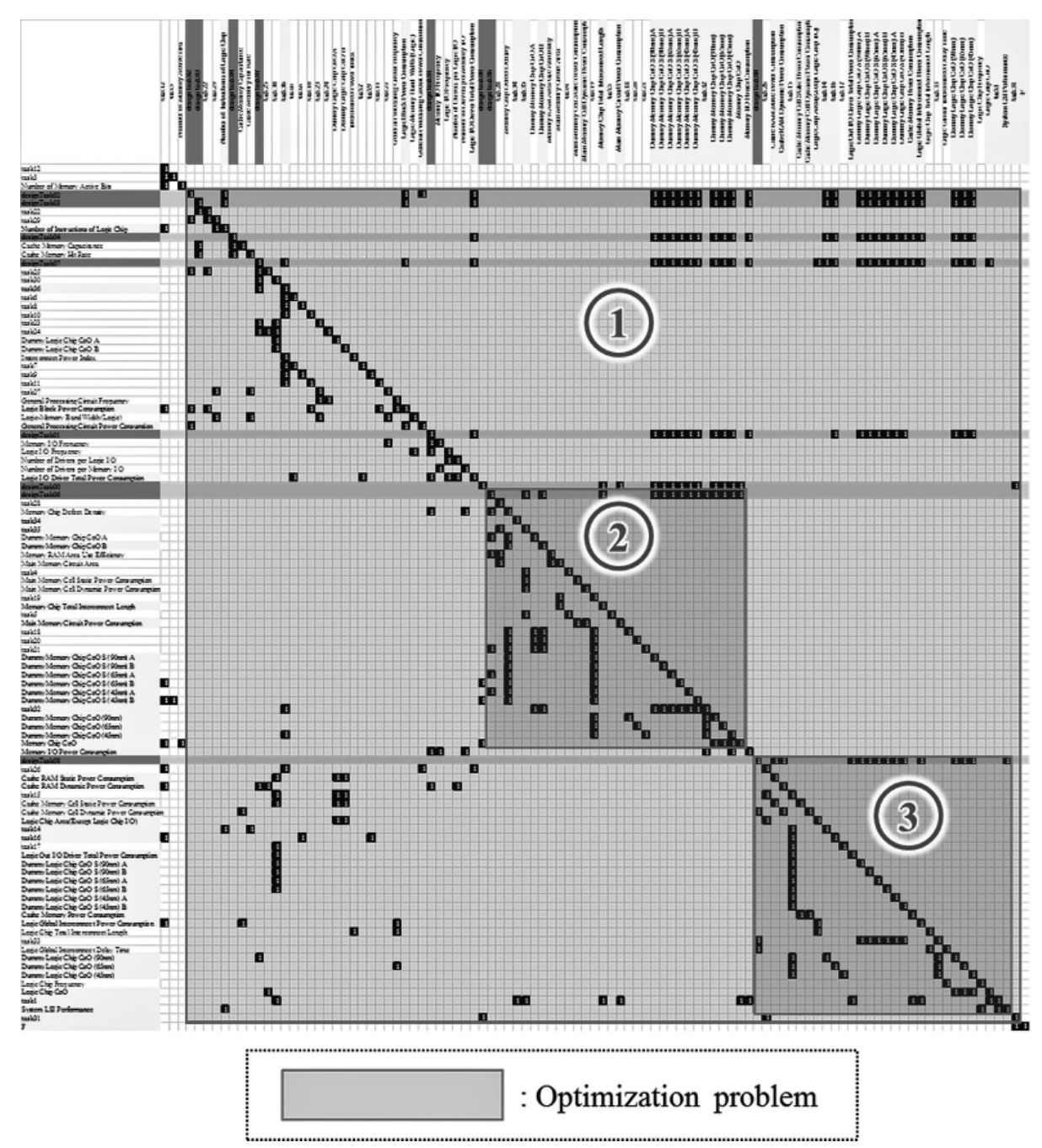

Fig. 8 The result of decomposing and hierarchizing of 3D-LSI optimization problem based on the proposal decomposing/hierarchizing algorithm.

（b）新階層型最適化手法の分割・階層化の実行結果

次に、本研究で構築した階層型最適化手法の分割・階層 化アルゴリズムによる分割・階層化結果を示す。ただし、 同時に自動分割・階層化手法のアルゴリズムの検証も行う ため、分割・階層化のプログラムの途中段階の実行結果に ついても述べていく。

まず、関係式分析プログラムの実行結果について述べる。 3 次元 LSI の設計の単目的最適化問題に、元々定義されて いた目的関数が F、一つであったのに対し、関係式分析の 結果、 $\mathrm{F}$ 以外に 145 個のパラメータが明確な最適化方向 (最 大化、あるいは最小化)が割り当てられ、目的関数に新た に定義できた。

最後に、分割・階層化プログラムの実行した結果の DSM と、それによって最終的に導出された、分割・階層 化された最適化問題を Fig. 8 に示す。DSMの各項目の濃 い灰色が目的関数で、薄い灰色が設計変数である。Fig. 8 より、目的関数から設計変数に付与した最適化計算の フィードバックループ (図中の (2)、(3)の四角の中の最上段
の黒四角の存在) 以外のフィードバックループ (図中の (2)、 (3)の四角の中の対角線より右上の部分に黒四角の存在) が ないことが分かる。また、本来なかった依存関係の出現も 確認できなかった。

以上より、本研究で構築した分割・階層化アルゴリズム と、自動分割・階層化手法の各アルゴリズムの妥当性を示 すことができた。

\section{4. 結 言}

製品モデルに基づく最適化問題分割について検討を行っ た。その結論を以下にまとめる。

（1）最適化問題の設計変数と目的関数の依存関係に着目し、 その関係をマトリックスにより整理・操作することによ り最適化問題を目的関数が確実に定義でき、最適化可能 な問題に分割・階層化するアルゴリズムを構築した。

(2) 3DLSI の概略設計に適用し、従来のモノや機能による 分割とは異なる最適化問題としての分割手法を提案し、 最適化問題の再定義ができる問題分割ができることを確 
認した。

\section{参考文献}

1) N. Srinivas, Kalyanmoy Deb: Multiobjective Optimization Using Nondominated Sorting in Genetic Algorithms, Evolutionary Computation, 2-3 (1994) 221-248.

2）渡邊真也、廣安知之、三木光範：近傍培養型遺伝的アルゴリ ズムによる多目的最適化”、情報処理学会論文誌、43-SIG 10 (2002) 183-198.

3) Yu-Jun Zheng, Sheng-Yong Chen: Cooperative particle swarm optimization for multiobjective transportation planning, Applied Intelligence, 39-1 (2013) 202-216.

4) Whei-Min Lin, Fu-Sheng Cheng, Ming-Tong Tsay: An Improved Tabu Search for Economic Dispatch With Multiple Minima, IEEE TRANSACTIONS ON POWER SYSTEMS, 17-1 (2002) 108-112.

5) Eckart Zitzler, Lothar Thiele: An Evolutionary Algorithm for Multiobjective Optimization: The Strength Pareto Approach, TIKReport, 43 (1998) Computer Engineering and Communication Networks Lab (TIK).

6) Eckart Zitzler, Marco Laumanns, Lothar Thiele, "SPEA2: Improving the Strength Pareto Evolutionary Algorithm”, TIK-Report 103 (2001), Computer Engineering and Communication Networks Lab (TIK).

7) Hyung Min Kim, Huei Peng, Nestor F. Michelena, Tao Jiang, John R.
Birge, Panos Y. Papalambros: Target Cascading in Optimal System Design, Transactions of the ASME, Vol. 125 (2001).

8) Debiao Meng, Xiaoling Zhang, Hong-Zhong Huang, Zhonglai Wang, Huanwei Xu: Interaction Prediction Optimization in Multidisciplinary Design Optimization Problems, The Science World Journal, Vol. 4 (2014).

9）岩田剛治、安村孝成、村田秀則、佐藤了平：システムデザイ ンに扔ける階層型多目的最適化手法の基礎的検討、日本機械 学会 第 20 回設計工学・システム部門講演会講演論文集 (2010) (1205-1)-(1205-6).

10）小森茂明、吉村允孝、泉井一浩：評価特性間の相関関係に着 目した階層構造化に基づく最適化戦略、日本機械学会 第 11 回設計工学・システム部門講演会講演論文集、(2001) 90-93.

11）村田秀則、岩田剛治、佐藤了平、森永英二、岡本和也、青山和浩、 古賀毅：システム定義手法を用いたシステムデザインに拀け る自動最適化アルゴリズムに関する研究、スマートプロセス 学会誌、3-1 (2014) 67-75.

12) M. D. Geunov, S. G. Barker: Application of Axiomatic Design and Design Structure Matrix to the Decomposition of Engineering Systems, Systems Engineering, 8-1 (2005) 29-40.

\section{代表者メールアドレス}

岩田剛治ｉwata@mapse.eng.osaka-u.ac.jp 